\title{
Correction to: A model of digital identity for better information security in e-learning systems
}

\author{
Dragan Korać ${ }^{1}$ Boris Damjanović ${ }^{2} \cdot$ Dejan Simić $^{3}$
}

Published online: 11 August 2021

๑) Springer Science+Business Media, LLC, part of Springer Nature 2021

\section{Correction to: The Journal of Supercomputing https://doi.org/10.1007/s11227-021-03981-4}

In this article, ref. 43 was incorrect.

The correct version is given below:

Korać D, Simić D (2014) Digital identity in identity management models. In: Proceeding of the 2014 International Conference on ICT Conference and Exibition, Aranđelovac, InfoTech 2014.

The original article has been corrected.

Publisher's Note Springer Nature remains neutral with regard to jurisdictional claims in published maps and institutional affiliations.

The original article can be found online at https://doi.org/10.1007/s11227-021-03981-4.

Dragan Korać

dragan.korac@pmf.unibl.org

Boris Damjanović

dboris65@gmail.com

Dejan Simić

simic.dejan@fon.bg

1 University of Banja Luka, Banja Luka, Bosnia and Herzegovina

2 University of Union Nikola Tesla, Beograd, Serbia

3 FON, University of Belgrade, Beograd, Serbia 